\title{
Timing of Macronutrient Supply during Cutting Propagation of Petunia
}

\author{
Kathryn M. Santos ${ }^{1}$, Paul R. Fisher, and Thomas Yeager \\ Department of Environmental Horticulture, University of Florida, P.O. Box \\ 110670, Gainesville, FL 32611 \\ Eric H. Simonne \\ Department of Horticulture Science, University of Florida, Gainesville, FL \\ 32611
}

Hannah S. Carter
Department of Agricultural Education and Communication, University of
Florida, Gainesville, FL 32611

William R. Argo

Blackmore Co., 10800 Blackmore Avenue, Belleville, MI 48111

Additional index words. foliar fertilization, greenhouse, mist, nitrogen, phosphorus, potassium

Abstract. The objective was to quantify the effect of the timing of macronutrient applications on nutrient uptake, growth, and development of Petunia $\times$ hybrida Hort. Vilm.-Andr. 'Supertunia Royal Velvet' during vegetative propagation. Starting with unrooted cuttings (Day 0), fertigation was applied continuously at three time intervals (Day 0 to 7, Day 8 to 14, or Day 15 to 21) using either a "complete" $(\mathbf{C})$ water-soluble fertilizer containing (in $\mathbf{~} g \cdot \mathbf{L}^{-1}$ ) $75 \mathrm{NO}_{3}-\mathrm{N}, 25 \mathrm{NH}_{4}-\mathrm{N}, 12$ phosphorus (P), 83 potassium (K), 20 calcium (Ca), 10 magnesium $(\mathrm{Mg}), 1.4$ sulfur $(\mathrm{S}), 2$ iron $(\mathrm{Fe}), 1$ manganese $(\mathrm{Mn}), 1$ zinc $(\mathrm{Zn}), 0.5$ copper $(\mathrm{Cu}), 0.5$ boron (B), and 0.2 molybdenum (Mo) or a micronutrient fertilizer (M) containing (in $\mathbf{m g} \cdot \mathrm{L}^{-1}$ ) $1.4 \mathrm{~S}$, $2 \mathrm{Fe}, 1 \mathrm{Mn}, 1 \mathrm{Zn}, 0.5 \mathrm{Cu}, 0.5 \mathrm{~B}$, and $0.2 \mathrm{Mo}$ in a complete factorial arrangement. With constant fertigation using the $C$ fertilizer, plant dry weight (DW) doubled from Day 0 (sticking of unrooted cuttings) to Day $7(0.020 \mathrm{~g}$ to $0.047 \mathrm{~g})$, root emergence was observed by Day 4, and by Day 7, the average length of primary roots was $2.6 \mathrm{~cm}$. During any week that the $M$ fertilizer was substituted for the $C$ fertilizer, tissue $\mathbf{N}-\mathbf{P}-\mathbf{K}$ concentrations decreased compared with plants receiving the $\mathrm{C}$ fertilizer. For example, plants receiving the $\mathrm{M}$ fertilizer between Day 0 and 7 had 20\% lower tissue-N concentration at Day 7 compared with those receiving the $C$ fertilizer. Although both shoot $D W$ and leaf count increased once macronutrient fertilization was resumed after Day 7, final shoot DW and leaf count were lower than plants receiving $C$ fertilizer from Day 0 to 21. Time to first root emergence was unaffected by fertigation. Constant application of $\mathrm{C}$ resulted in a higher shoot-to-root ratio at Day 21 than all other treatments. Results emphasize the importance of early fertigation on petunia, a fast-rooting species, to maintain tissue nutrient levels within recommended ranges.

Appropriate timing and concentration of nutrient supply in vegetative cutting propagation affects root development, uniformity of plant growth, uptake efficiency [(nutrient taken up/total nutrient applied-nutrients in substrate)*100], nutrient runoff, and transplant success. Root development can be divided into four stages: 1) cutting condition at "sticking" (insertion) into substrate; 2) callus formation; 3) root development; and 4) toning (Dole and

Received for publication 31 Aug. 2009. Accepted for publication 21 Dec. 2010.

We thank the USDA-ARS Floriculture and Nursery Research Initiative, Blackmore Co., Ellegaard, Fafard, Greencare Fertilizers, Jiffy Products of America, Pindstrup, Premier Horticulture, Quality Analytical Laboratories, Sun Gro Horticulture, leading growers in the Young Plant Research Center (www.floriculturalliance.org), and the University of Florida IFAS for financial support of this project.

${ }^{1}$ To whom reprint requests should be addressed; e-mailksantos@costafarms.com.
Gibson, 2006). Fertigation recommendations for vegetative cuttings are currently correlated with root developmental stages with a recommended initial application of 50 to $75 \mathrm{mg} \mathrm{N} / \mathrm{L}$ at visible callus development (Stage 2) and subsequent applications of $100 \mathrm{mg} \mathrm{N} / \mathrm{L}$ after root emergence (i.e., during Stage 3) (Dole and Gibson, 2006). Nutrient availability in the substrate becomes particularly important for uptake at Stage 3 after root emergence. Nutrients can be supplied to vegetative cuttings through a combination of preplant dry fertilizers in the substrate, supplemental application of water-soluble fertilizer, and/or incorporation of controlled-release fertilizers. Historically, fertilization through overhead mist was not recommended for short-term crops as a result of the potential for clogged emitters and algae growth (Dole and Gibson, 2006).

Based on a survey of eight U.S. commercial greenhouses, the concentration of fertilizer solutions applied during the propagation of vegetative petunia and calibrachoa cuttings ranged from 0.5 to 80 and 64 to $158 \mathrm{mg} \cdot \mathrm{L}^{-1} \mathrm{~N}$ for 7 and $28 \mathrm{~d}$ after sticking into substrate, respectively (Santos et al., 2008). Timing of fertigation varied from constant application of $\mathrm{N}$ for $28 \mathrm{~d}$ to application of $\mathrm{N} 14 \mathrm{~d}$ after sticking (Santos et al., 2008). The variation in observed practices at these operations suggests that the current recommended fertilization strategies may need to be refined with further consideration of fertilizer timing and $\mathrm{N}$ concentration.

Mist irrigation is intended to maintain cutting turgidity during root development and often water is supplied in excess of evapotranspiration loss and container capacity (representing the volume of water held in a drained substrate) resulting in the potential for rapid leaching of fertilizer (Kerr and Hanan, 1985; Mudge, 1995; Santos et al., 2008). Propagators surveyed leached as much as $46 \mathrm{~L} \cdot \mathrm{m}^{-2}$ in a 4-week crop cycle and six of eight operations leached over one container capacity during the same period (Santos et al., 2008). Nutrient leaching as a consequence of mist application during propagation is significant because soilless substrates have a limited ability to retain nutrients, especially when total leaching rates are greater than one container capacity (Biernbaum et al., 1995; Kerr and Hanan, 1985). During Stages 1 and 2 of root development, the loss of nutrients from leaching could deplete the substrate of nutrients by Stage 3 (root emergence), a critical stage for nutrient replenishment for the cutting. Therefore, commercial fertilizer application early in propagation before root formation may be required to recharge leached nutrients from the substrate. Water-soluble fertilizer applications before root emergence may also facilitate foliar uptake of nutrients (Tukey et al., 1958) and reduce observed tissue nutrient declines during preliminary phases of propagation (Svenson and Davies, 1995; Wilkerson and Gates, 2005).

Timing the supply of fertilizer to meet plant requirements at different root developmental stages has the potential to increase uptake efficiency and reduce nutrient runoff. Macronutrients, in absolute terms, are required in higher quantities compared with micronutrients only. Therefore, plant response to macronutrient supply is of particular interest before significant root growth (Phases 1 and 2 of rooting). The objective of this research was to evaluate the effect of timing of macronutrient supply on growth and nutrient uptake of petunia cuttings at 0 to 7,8 to 14 , and 15 to $21 \mathrm{~d}$ after sticking, in which these time periods correspond to mist fertigation during callus and root initial formation from Days 0 to 7 followed by hand fertigation during the root growth phase from Days 8 to 21 .

\section{Materials and Methods}

The experiment was conducted at the University of Florida, Environmental Horticulture Research Greenhouse Complex in Gainesville, FL, from 27 Mar. 2007 to 18 Apr. 2007. Greenhouse and irrigation management were controlled by an environmental control system (Hortimax, Pijnacker, The Netherlands). 
Unrooted cuttings of Petunia $\times$ hybrida Hort. Vilm.-Andr. 'Supertunia Royal Velvet' were air-freighted over $2 \mathrm{~d}$ from an off-shore vegetative cutting supplier, InnovaPlant in Costa Rica. Cuttings were immediately inserted into $21 \times 50 \mathrm{~cm}, 102$-count $(19.6 \mathrm{~mL} /$ cell $)$ propagation trays filled with $70 \%$ peat $/ 30 \%$ perlite (by volume) substrate containing $2.1 \mathrm{~kg} \cdot \mathrm{m}^{-3}$ hydrated lime and $0.14 \mathrm{~L} \cdot \mathrm{m}^{-3}$ wetting agent (AquaGro 2000 M, Aquatrols, NJ). Substrate container capacity was $2.3 \mathrm{~L} /$ tray. The experimental unit was defined as an individual $(21 \times$ $50 \mathrm{~cm}$; 102 count) propagation tray.

Mist was provided by bench risers fitted with $1.2 \mathrm{~L} \cdot \mathrm{min}^{-1}$ JetRain nozzles (Dramm, Manitowac, WI) spaced $91.4 \mathrm{~cm}$ apart and alternated $30.5 \mathrm{~cm}$ and $40.6 \mathrm{~cm}$ above the crop until roots reached the side and bottom of each cell (14 d after sticking). Mist frequency was adjusted according to light, temperature, and root development stages. Average light levels were $216.4 \mu \mathrm{mol} \cdot \mathrm{m}^{-2} \cdot \mathrm{s}^{-1}$ per day with average temperatures of $23^{\circ} \mathrm{C}$ during the day and $19^{\circ} \mathrm{C}$ at night. Before significant root growth (root length less than $3 \mathrm{~cm}$ ), the mist frequency was every 17 to $28 \mathrm{~min}$ for $5 \mathrm{~s}$ triggered by an accumulated light threshold of 200 $\mathrm{mmol} \cdot \mathrm{m}^{-2}$ of photosynthetically active radiation light. After root length was greater than $3 \mathrm{~cm}$, the light threshold was increased to 500 $\mathrm{mmol} \cdot \mathrm{m}^{-2}$ resulting in a mist frequency of every 50 to $60 \mathrm{~min}$ for $5 \mathrm{~s}$.

Constant fertigation with a " $\mathrm{C}$ " watersoluble fertilizer containing (in $\mathrm{mg} \cdot \mathrm{L}^{-1}$ ) 75 $\mathrm{NO}_{3}-\mathrm{N}, 25 \mathrm{NH}_{4}-\mathrm{N}, 12 \mathrm{P}, 83 \mathrm{~K}, 20 \mathrm{Ca}, 10 \mathrm{Mg}$, $1.4 \mathrm{~S}, 2 \mathrm{Fe}, 1 \mathrm{Mn}, 1 \mathrm{Zn}, 0.5 \mathrm{Cu}, 0.5 \mathrm{~B}$, and 0.2 Mo combined with a deionized water source was supplied through the mist system for the first 2 weeks and by hand for the last week (27 Mar. 2007 to 18 Apr. 2007). Fertilizer salts used were ammonium nitrate, ammonium phosphate, calcium nitrate, magnesium nitrate, potassium nitrate, boric acid, copper sulfate, iron EDDHA, manganese sulfate, sodium molybdate, and zinc sulfate. For Days 7,14 , and/or 21, as shown in Table 1, the alternative fertilizer treatment ("M") contained only the micronutrient salts of the $\mathrm{C}$ fertilizer and was considered the control. Clear water was not used as the control because the objective was to evaluate the effect of macronutrient fertilizer supply only on growth and tissue nutrient trends in petunia. After $14 \mathrm{~d}$, cuttings were irrigated with the fertilizer solutions twice a week (i.e., with the same frequency for all treatments) by hand using a hose fitted with a 1000PL water breaker (Dramm) for the remaining $7 \mathrm{~d}$. Fertilizer solutions were pumped from separate 378.6-L stock tanks beneath each bench. Irrigation volume applied was 4.0 and $2.3 \mathrm{~L}$ for 7 and 14 to $21 \mathrm{~d}$ after sticking, respectively, resulting in total leaching of $1.1 \mathrm{cc}$ over 3 weeks. Average volume leached was 1.2 and $0.7 \mathrm{~L}$ per experimental unit 7 and 14 to $21 \mathrm{~d}$ after sticking, respectively.

The experiment was divided into four blocks, each consisting of the eight treatments described in Table 1. At the start of the experiment, each block contained six replicate trays per treatment combination. Two experimental units (trays) per treatment were collected from each block on each measurement date $(0,7,14$, and $21 \mathrm{~d}$ after sticking) and destructively sampled $(n=8)$.

Data were analyzed using Proc GLM in SAS (Version 9.1; SAS Institute, Cary, NC) as a randomized complete block design with each block consisting of varying intervals of $\mathrm{C}$ and $\mathrm{M}$ treatments. A separate analysis of variance was run for each measurement date, because the treatment combinations changed over time (C and $\mathrm{M}$ at Day 7, CC, CM, MC, and $\mathrm{MM}$ at Day 14, etc.). Means were analyzed using Tukey's honestly significant difference test at $P \leq 0.05$. Data collected from each experimental unit included SPAD chlorophyll index (Minolta SPAD 502; Spectrum Technologies, Plainfield, IL), number of leaves per cutting, plant height, longest root length, rooting stage, dry weight, and shoot and root tissue samples for nutrient analysis. Rooting stage for each treatment was determined using a rooting scale defined by Dole and Gibson (2006).

Tissue $\mathrm{N}$ concentration was measured as total Kjeldahl $\mathrm{N}$ where protein was converted to $\mathrm{NH}_{4}$ using heat, a catalyst, sulfuric acid, and hydrogen peroxide. The sample was then run on a spectrophotometer (DR 4000; Hach, Loveland, CO) using Nesslerization for $\mathrm{N} \mathrm{de-}$ termination. A Hach Digestahl apparatus was used for the conversion (digestion) and a spectrophotometer (DR 4000) for the analysis. Analysis of $\mathrm{P}, \mathrm{K}, \mathrm{Ca}, \mathrm{Mg}, \mathrm{Na}, \mathrm{Fe}, \mathrm{Mn}, \mathrm{Zn}$, $\mathrm{Cu}, \mathrm{B}$, and $\mathrm{Mo}$ was accomplished by dry ashing digestion followed by inductively coupled plasma (ICP) emission spectrometry by Quality Analytical Laboratories (Panama

Table 1. Fertilization treatments applied to Petunia $\times$ hybrida over a $21-\mathrm{d}$ crop cycle. ${ }^{2}$

\begin{tabular}{lcccc}
\hline Treatment & 0 to 7 days & 8 to 14 days & 15 to 21 days & Code \\
\hline 1 & $\mathrm{C}$ & $\mathrm{C}$ & $\mathrm{C}$ & CCC \\
2 & $\mathrm{C}$ & $\mathrm{C}$ & $\mathrm{M}$ & CCM \\
3 & $\mathrm{C}$ & $\mathrm{M}$ & $\mathrm{M}$ & $\mathrm{CMM}$ \\
4 & $\mathrm{C}$ & $\mathrm{M}$ & $\mathrm{M}$ & $\mathrm{CMC}$ \\
5 & $\mathrm{M}$ & $\mathrm{M}$ & $\mathrm{C}$ & $\mathrm{MMM}$ \\
6 & $\mathrm{M}$ & $\mathrm{M}$ & $\mathrm{C}$ & $\mathrm{MMC}$ \\
7 & $\mathrm{C}$ & $\mathrm{C}$ & $\mathrm{MCC}$ \\
8 & $\mathrm{C}$ & $\mathrm{C}$ & $\mathrm{MCM}$ \\
\hline
\end{tabular}

" $\mathrm{C}$ " represents constant fertigation with a "complete" water-soluble fertilizer containing (in $\mathrm{mg} \cdot \mathrm{L}^{-1}$ ) 75 $\mathrm{NO}_{3}-\mathrm{N}, 25 \mathrm{NH}_{4}-\mathrm{N}, 12$ phosphorus $(\mathrm{P}), 83$ potassium $(\mathrm{K}), 20$ calcium $(\mathrm{Ca}), 10$ magnesium $(\mathrm{Mg}), 1.4$ sulfur (S), 2 iron (Fe), 1 manganese (Mn), 1 zinc ( $\mathrm{Zn}), 0.5$ copper $(\mathrm{Cu}), 0.5$ boron (B), and 0.2 molybdenum (Mo). "M"' represents fertilization with micronutrients only (1.4 S, $2 \mathrm{Fe}, 1 \mathrm{Mn}, 1 \mathrm{Zn}, 0.5 \mathrm{Cu}, 0.5 \mathrm{~B}$, and $0.2 \mathrm{Mo}$ ). Treatment labels used in the text (listed under the "Code" column) are made up of three letters, in which the first letter corresponds to the fertilizer treatment on Week 1, the second letter for Week 2, and so forth.
City, FL) using a ICAP 61E (Thermo- Jarrell Ash, Franklin, MA). Samples consisted of either the total cuttings $7 \mathrm{~d}$ after sticking to provide sufficient tissue for complete nutrient analysis or separated roots and shoots 14 and $21 \mathrm{~d}$ after sticking. Cutting nutrient content was calculated by multiplying cutting dry weight in milligrams by the decimal fraction of the percent $\mathrm{N}, \mathrm{P}$, or $\mathrm{K}$, respectively, and nutrient uptake was calculated by subtracting grams of $\mathrm{N}, \mathrm{P}$, or $\mathrm{K}$ on Day 0 from the measurement date (milligrams of $\mathrm{N}, \mathrm{P}$, or $\mathrm{K}$ on Day 7,14 , or 21 ).

Two additional experimental units per bench were randomly selected every $7 \mathrm{~d}$ (4, 7, and 18 Apr. 2007) for substrate and leachate nutrient sampling. The plug press method was used to sample substrate by pressing down firmly on the top of the substrate surface and the solution was collected from the hole at the bottom of the pressed plug cell (Scoggins et al., 2002). Solution leached from the propagation trays was measured in collection trays following the protocol described by Santos et al. (2008). Solutions were submitted for nutrient analysis using ICP to measure $\mathrm{P}, \mathrm{K}$, $\mathrm{Ca}, \mathrm{Mg}, \mathrm{S}, \mathrm{Fe}, \mathrm{Mn}, \mathrm{B}, \mathrm{Cu}, \mathrm{Zn}, \mathrm{Mo}$, aluminum, and sodium. The leachate and substrate solution samples were analyzed for $\mathrm{NO}_{3}-\mathrm{N}$ and ammonium $\left(\mathrm{NH}_{4}\right) \mathrm{N}$ using a Lachat QuikChem $\mathrm{AE}$ (Lachat Instruments, Loveland, $\mathrm{CO}$ ), and total $\mathrm{N}$ was calculated as $\mathrm{NO}_{3}-\mathrm{N}$ plus $\mathrm{NH}_{4}$.

\section{Results and Discussion}

Shoot and root growth. Macronutrient supply $(\mathrm{C})$ during the first $7 \mathrm{~d}$ of production increased total dry weight by $21 \mathrm{~d}$ after sticking compared with fertilization with $\mathrm{M}$ during the first $7 \mathrm{~d}$ (Table 2; Fig. 1A). There was $100 \%$ rooting in all treatments with all cuttings tested at rooting Stage 2 (visible callus formation) on Day 4 and root development (Stage 3) occurring from Day 5 onward. At Day 7, total dry weight therefore consisted primarily of shoots only (roots were too small to separate and measure dry weight accurately). Total dry weight for plants receiving $M$ treatments did not differ from constant $\mathrm{C}$ dry weight until $21 \mathrm{~d}$ after sticking, at which point treatments CMM, $\mathrm{CMC}, \mathrm{CCM}$, and $\mathrm{CCC}$ were consistently higher in total dry weight than other treatments (MMM, MMC, MCM, and MCC).

Shoot dry weight increased by Day 7 from 0.020 to $0.042 \mathrm{~g} /$ cutting; however, there was no difference in shoot dry weight between $\mathrm{C}$ and $\mathrm{M}$ plants (Table 2; Fig. 1A). Continued fertigation with the $\mathrm{C}$ fertilizer resulted in increased shoot dry weight compared with $\mathrm{M}$ supply by Days 14 and 21 (Table 2; Fig. 1B). Shoot dry weight was greater in CC $(0.064 \mathrm{~g} /$ cutting) compared with that of treatments that received MC (0.051 g/cutting). The lowest shoot DWs at $21 \mathrm{~d}$ after sticking were found in MMM or MMC plants ( 0.069 or $0.065 \mathrm{~g} /$ cutting), respectively (Fig. 1B).

Continued application of $\mathrm{C}$ fertilizer at $21 \mathrm{~d}$ after sticking (CCC) resulted in reduced root DW compared with macronutrient supply during the first $7 \mathrm{~d}$ only (the CMM treatment; Fig. 1C). Treatments did not affect root length 
Table 2. Analysis of variance summary of $P$ values for fertilizer treatment effects on cumulative cutting dry weights and tissue nitrogen percent, content, and uptake per week from combined roots and shoots. ${ }^{2}$

\begin{tabular}{lccr}
\hline & \multicolumn{3}{c}{ Time period } \\
\cline { 2 - 4 } Variable & 0 to 7 days & 8 to 14 days & 15 to 21 days \\
\hline Root dry weight (g/cutting) & $\mathrm{NA}$ & 0.2314 & $<0.0001$ \\
Shoot dry weight (g/cutting) & 0.4165 & 0.0169 & $<0.0001$ \\
Total dry weight (g/cutting) & 0.4165 & 0.1591 & $<0.0001$ \\
Shoot:root dry weight ratio & $\mathrm{NA}$ & 0.0002 & $<0.0001$ \\
Tissue N concentration (mg/cutting) & 0.0012 & $<0.0001$ & $<0.0001$ \\
Tissue N content (mg/cutting) & 0.0029 & $<0.0001$ & $<0.0001$ \\
Tissue N uptake (mg/cutting per week) & 0.0119 & 0.0004 & 0.0011 \\
\hline
\end{tabular}

${ }^{2}$ Root growth was sufficient to measure root dry weight from Day 14 onward. Treatment labels are made up of one, two, or three letters, in which the first letter corresponds to the fertilizer treatment on Week 1, the second letter for Week 2, and so forth. For the period 0 to 7 days, treatment combinations were $\mathrm{M}$ (micronutrients only) and $\mathrm{C}$ (complete fertilizer). For the period 8 to 14 days, treatment combinations included MM, MC, CM, and CC; and for the period 15 to 21 days, MMM, MMC, MCM, MCC, CMM, $\mathrm{CMC}, \mathrm{CCM}$, and CCC. Least square means data are summarized in Figure 1 for dry weights and Figure 2 for tissue nitrogen.

$\mathrm{NA}=$ not applicable.

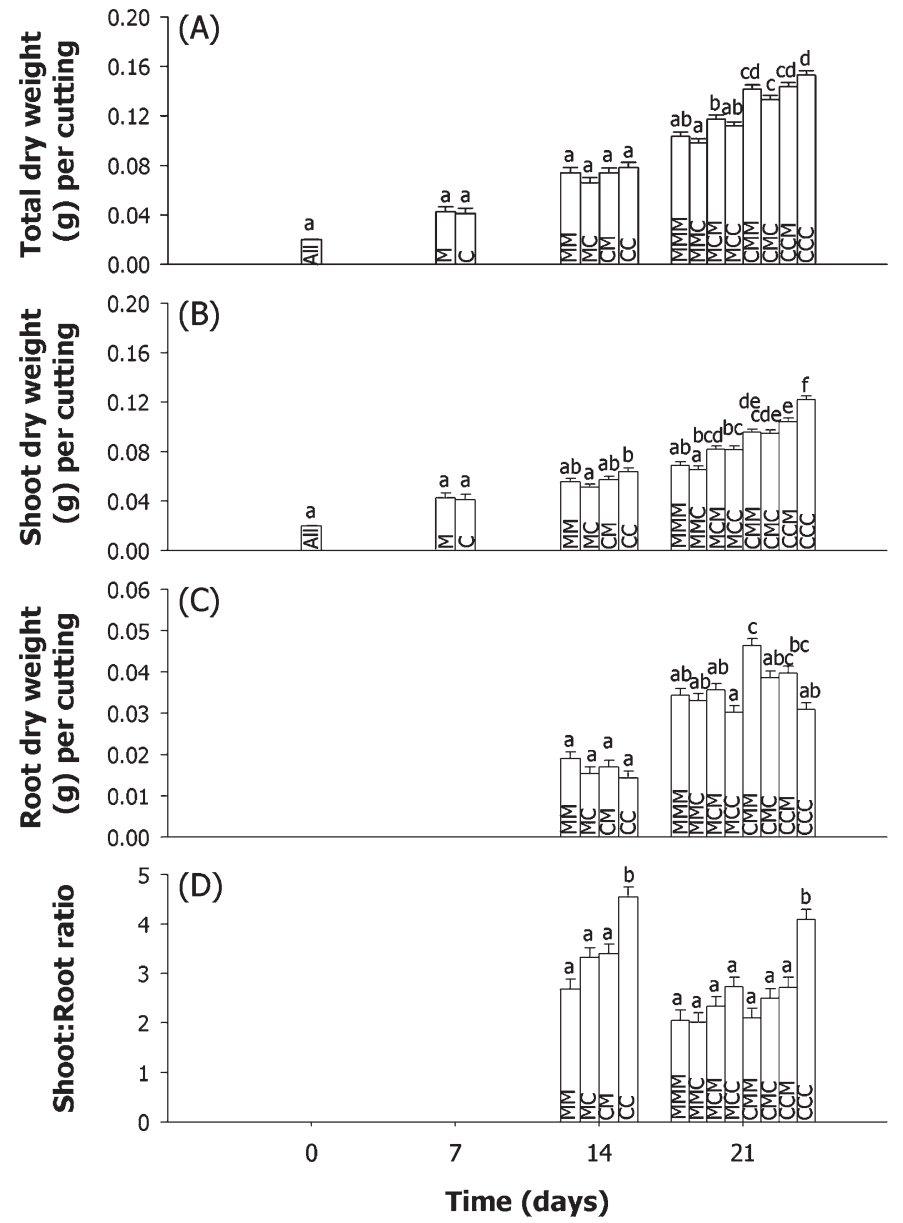

Fig. 1. Measured total dry weight (A), shoot dry weight (B), root dry weight (C), and shoot:root ratio (D) per cutting over time. Root dry weight was measured when root length was greater than $3 \mathrm{~cm}$, corresponding to $14 \mathrm{~d}$ after sticking. Root emergence began at Day 4, regardless of treatment. Roots were not separated from shoots until $14 \mathrm{~d}$ after sticking. White bars correspond to each data collection interval and treatment calculated from the average of eight randomly selected trays (two trays per block) divided by the number of cuttings per tray (102). "C" represents the "complete" fertilizer treatment and " $\mathrm{M}$ " represents the micronutrient fertilizer treatment during a given week. Treatment labels are made up of one, two, or three letters, in which the first letter corresponds to the fertilizer treatment on Week 1, the second letter for Week 2, and so forth. Means were separated within each date using Tukey's honestly significant difference test at $P \leq 0.05$.

$(P=0.767$ at Day 14 and 0.105 on Day 21$)$ and average root length increased to $2.6,12.2$, and $17.9 \mathrm{~cm} /$ cutting by 7,14 , or $21 \mathrm{~d}$ after sticking, respectively. tion time required to produce a well-rooted, compact plant. Increasing the duration of $\mathrm{C}$ fertilization increased the S:R (Fig. 1D). The $\mathrm{S}: \mathrm{R}$ ratio at Day 14 was higher in $\mathrm{CC}$ plants (4.5) compared with plants that received the other three treatments (which averaged 3.2). The S:R ratio continued to be highest at $21 \mathrm{~d}$ in the CCC treatment (4.1) compared with an average of 2.4 for the other seven treatments.

Constant $\mathrm{C}$ fertilizer application increased shoot height and leaf number (Table 3). Plant height averaged $1.7 \mathrm{~cm}$ to $2.1 \mathrm{~cm} /$ cutting and leaf number was 4.2 or 5.4 leaves/cutting on Days 0 and 7, respectively, regardless of fertilizer treatment. At $14 \mathrm{~d}$, cuttings that received the $\mathrm{CC}$ treatment were taller than $(4.5 \mathrm{~cm})$ the cuttings that received the $\mathrm{MM}$ treatment $(3.5 \mathrm{~cm})$. At $21 \mathrm{~d}, \mathrm{CCC}$ plants were the tallest of all treatments $(8.3 \mathrm{~cm})$ and MMM were the shortest $(3.6 \mathrm{~cm})$. Leaf number was highest in $\mathrm{CC}$ plants (8.1 leaves/cutting), whereas treatments $\mathrm{CM}$ or $\mathrm{MC}$ had the lowest leaf counts (6.5 leaves/cutting) after $14 \mathrm{~d}$. After $21 \mathrm{~d}$, leaf number remained highest in CCC or CCM plants (10.7 or 10.4 leaves/ cutting). The lowest leaf counts were observed in plants receiving the MMM (7.0 leaves/ cutting) or MMC (7.2 leaves/cutting) treatments. Treatments affected SPAD chlorophyll index only at $14 \mathrm{~d}$ after sticking $(P<0.0001)$, but with only a small range in SPAD index values [highest in MC plants (32.7) and lowest in $\mathrm{CM}$ (28.7)].

Nutrient concentration. Tissue nutrient concentration decreased from Day 0 to 7 in plants from all fertilizer treatments (Fig. 2A). With continuous application of the $\mathrm{C}$ fertilizer, tissue-N concentration dropped from $6.6 \%$ on Day 0 to $4.8 \%$ on Day $7,5.0 \%$ on Day 14 , and $4.3 \%$ on Day 21 (Fig. 2A). Percent P and K concentrations followed a similar trend to $\mathrm{N}$ under constant application of $\mathrm{C}$ with decreasing nutrient concentrations over the first $14 \mathrm{~d}$ followed by stable to slightly increasing concentrations (data not shown).

A greater decline in tissue nutrient concentration occurred during the first week when $\mathrm{M}$ was provided (Table 2; Fig. 2A). Cuttings that received $\mathrm{M}$ had $3.7 \% \mathrm{~N}, 0.3 \% \mathrm{P}$, and $2.7 \%$ $\mathrm{K}(1.6,0.10$, and $1.1 \mathrm{mg} / \mathrm{cutting})$ at Day 7 compared with $4.8 \% \mathrm{~N}, 0.5 \% \mathrm{P}$, and $3.7 \% \mathrm{~K}$ $(2.0,0.20$, and $1.5 \mathrm{mg} /$ cutting) with the $\mathrm{C}$ fertilizer. The initial decrease in tissue nutrient concentrations could be attributed to dilution that resulted from an increase in total DW in conjunction with minimal uptake of nutrients (Blazich, 1988). Nutrients leached from the foliage, a phenomenon observed by Good and Tukey (1967), was not a factor in the initial tissue nutrient decline because a net loss of $\mathrm{N}$ per cutting was not observed during the first $7 \mathrm{~d}$ of propagation (Fig. 2B).

Application of $\mathrm{C}$ nutrient supply at any week in the crop cycle resulted in increased tissue $\mathrm{N}-\mathrm{P}-\mathrm{K}$ concentration at the end of that week compared with $\mathrm{M}$ ( $\mathrm{N}$ data in Fig. 2C; $\mathrm{P}$ and $\mathrm{K}$ data not shown). Tissue nutrient concentrations increased once $\mathrm{C}$ application resumed; however, regardless of treatment, tissue $\mathrm{N}-\mathrm{P}-\mathrm{K}$ concentrations did not return to initial percent nutrient concentrations, suggesting that 
Table 3. Summary analysis of variance results for effects of macronutrient fertilizer supply on plant height and leaf node number measured at Day 14 and $21 .^{\mathrm{z}}$

\begin{tabular}{llcc}
\hline Measurement day & Treatment & Plant ht $(\mathrm{cm})$ & Leaf node number (leaves/cutting) \\
\hline 14 days & MM & $3.5 \mathrm{~b}$ & $6.5 \mathrm{~b}$ \\
& MC & $4.0 \mathrm{ab}$ & $6.9 \mathrm{~b}$ \\
& CM & $4.2 \mathrm{a}$ & $8.0 \mathrm{a}$ \\
& CC & $4.5 \mathrm{a}$ & $8.1 \mathrm{a}$ \\
& $P$ value & 0.0026 & 0.0004 \\
& & \\
21 days & MMM & $3.6 \mathrm{f}$ & $6.9 \mathrm{c}$ \\
& MMC & $3.8 \mathrm{ef}$ & $7.2 \mathrm{c}$ \\
MCM & $4.8 \mathrm{de}$ & $8.6 \mathrm{~b}$ \\
MCC & $5.1 \mathrm{~cd}$ & $8.9 \mathrm{~b}$ \\
& CMM & $6.2 \mathrm{~b}$ & $9.6 \mathrm{ab}$ \\
& CMC & $6.1 \mathrm{bc}$ & $9.6 \mathrm{ab}$ \\
& CCM & $6.5 \mathrm{~b}$ & $10.4 \mathrm{a}$ \\
& CCC & $8.3 \mathrm{a}$ & $10.7 \mathrm{a}$ \\
& $P$ value & $<0.0001$ & $<0.0001$ \\
\hline
\end{tabular}

z"C" represents the "complete" fertilizer treatment and " $M$ " represents the micronutrient fertilizer treatment during a given week. Treatment labels are made up of one, two, or three letters, in which the first letter corresponds to the fertilizer treatment on Week 1, the second letter for Week 2, and so forth. Means were separated within each date using Tukey's honestly significant difference test at $P \leq 0.05$.
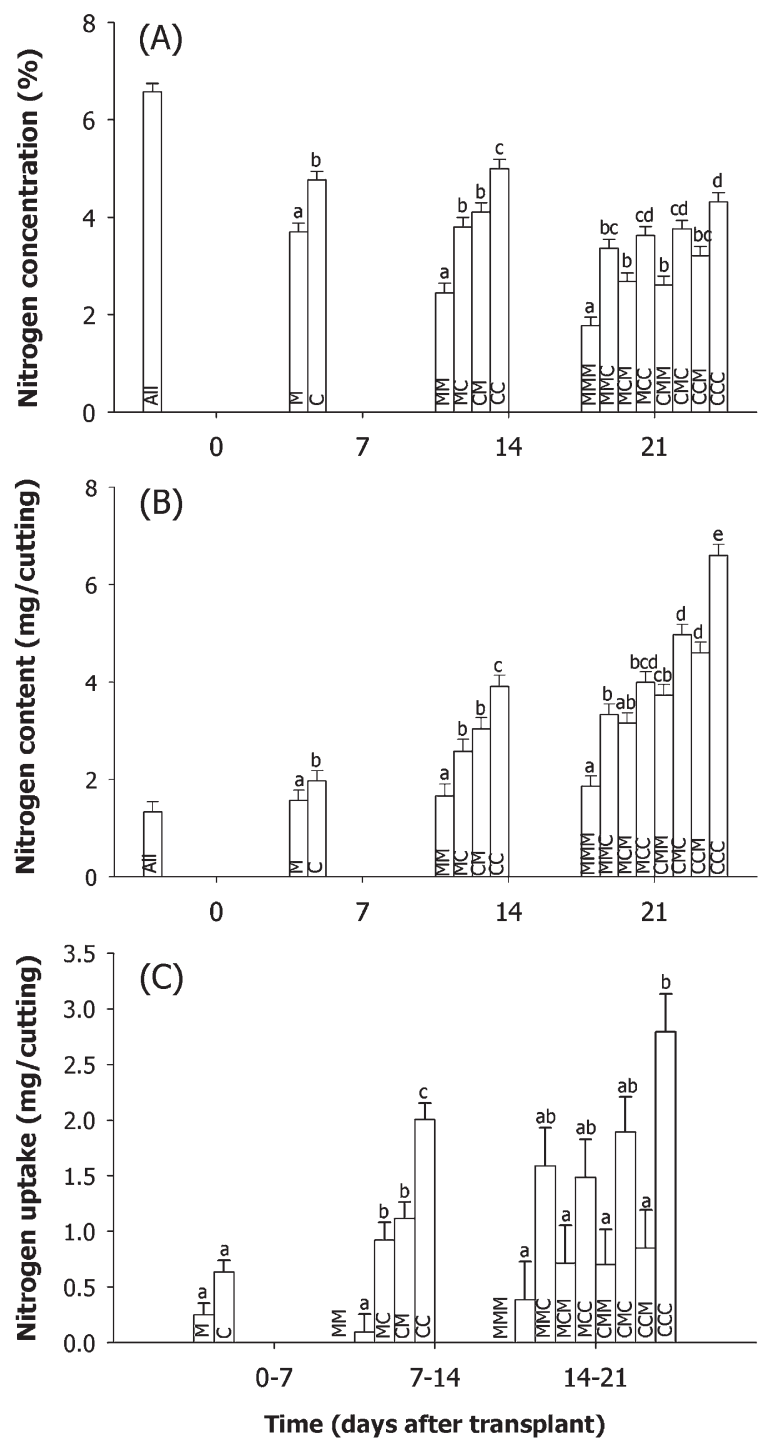

Fig. 2. Nitrogen $(\mathrm{N})$ content in the shoot and root by treatment over time expressed as percent of dry weight (A), milligrams per cutting (B), or (C) nitrogen uptake (milligrams per cutting per week). Nitrogen uptake was calculated using the following equation: [(Day 7, 14, or $21 \mathrm{DW}$ in $\mathrm{mg} /$ cutting $) \times($ the decimal fraction of the percent $\mathrm{N}$ at Day 7,14, or 21)] $-[$ (preceding week DW in $\mathrm{mg} /$ cutting) $\times$ (preceding tissue decimal fraction of the $\% \mathrm{~N})$ ] where DW = dry weight. "C" represents the "complete" fertilizer treatment and " $\mathrm{M}$ " represents the micronutrient fertilizer treatment during a given week. Treatment labels are made up of three letters; the first letter corresponds to the fertilizer treatment Week 1 and so forth. The mean separation used was Tukey's honestly significant difference test at $P \leq 0.05$. nutrient concentrations in the stock plant are very important to avoid nutrient deficiency symptoms in the unrooted cuttings (Rowe and Blazich, 1999). The goal throughout vegetative propagation is to maintain tissue nutrient concentrations within the recommended ranges to avoid slowed root and shoot development caused by nutrient deficiency. Gibson et al. (2007) observed deficiency symptoms in petunia at $2.1 \% \mathrm{~N}, 0.07 \% \mathrm{P}$, and $0.7 \% \mathrm{~K}$, whereas Mills and Jones (1996) reported minimum sufficiency concentrations of $3.9 \% \mathrm{~N}, 0.47 \%$ $\mathrm{P}$, and $3.1 \% \mathrm{~K}$ for petunia. In our study, $1.8 \%$ $\mathrm{N}, 0.2 \% \mathrm{P}$, and $1.5 \% \mathrm{~K}$ were observed for the MMM treatment at $21 \mathrm{~d}$, indicating that $\mathrm{N}$ had dropped to a deficient concentration compared with both Gibson et al. (2007) and Mills and Jones (1996) standards. Compared with the Mills and Jones (1996) standards only, tissue $\mathrm{P}$ and $\mathrm{K}$ were also below minimum sufficiency standards for the MMM treatment on Days 7, 14 , and 21

Nitrogen content (dry weight $\times$ tissue concentration; Fig. 2B) and also content of $\mathrm{P}$ and $\mathrm{K}$ (data not shown) increased each week that $\mathrm{C}$ fertilizer was applied. $\mathrm{N}$ uptake was different between fertilizer treatments by Day 14 (Fig. 2C). Weekly N uptake increased over time for plants that received $\mathrm{C}$ fertilizer. A small amount of $\mathrm{N}$ uptake did occur in plants receiving continuous $\mathrm{M}$, presumably from the peat substrate. By Week 3, N uptake in CCC-treated plants was nearly $10 \times$ nutrient uptake of MMM cuttings receiving $\mathrm{M}$ (MMM) on Days 0 to 21 (2.8 versus $0.39 \mathrm{mg} /$ cutting), respectively.

The fate of applied nutrients each week (leachate, substrate, or tissue; Fig. 3) showed increased tissue uptake and decreased leachate over time in the propagation cycle. The first week of propagation resulted in the least uptake efficiency [20\%, calculated as (plant uptake/nutrients applied)*100], which would be expected because root emergence did not occur until Day 4 and uptake would only occur through foliage and the cut stem. In commercial propagation conditions, the highest amount of leaching often occurs during the first $7 \mathrm{~d}$ of propagation because of the large water volume applied to maintain cutting turgidity (Santos et al., 2008). Uptake efficiency increased to $70 \%$ and $80 \%$ in Weeks 2 and 3 with the combination of a more developed root systems and reduced irrigation frequency.

Overall, the timing of macronutrient supply throughout a $21-\mathrm{d}$ propagation cycle was found to affect growth, development, and nutrient uptake of petunia cuttings. Growth was dependent on macronutrient supply, particularly in terms of shoot dry weight (Fig. 1). Continuous application of $\mathrm{C}$ fertilizer also resulted in more rapid development, as quantified by more leaves per plant (Table 3), when compared with plants that received $\mathrm{M}$ indicating that some macronutrient (probably $\mathrm{P}$ or $\mathrm{K}$ ) had reached a minimum critical concentration to limit growth. A high-quality "finished" rooted cutting requires adequate rooting, adequate shoot growth, and compact height. Therefore, under continuous $\mathrm{C}$ fertilizer, increased chemical or climate-controlled growth regulation 

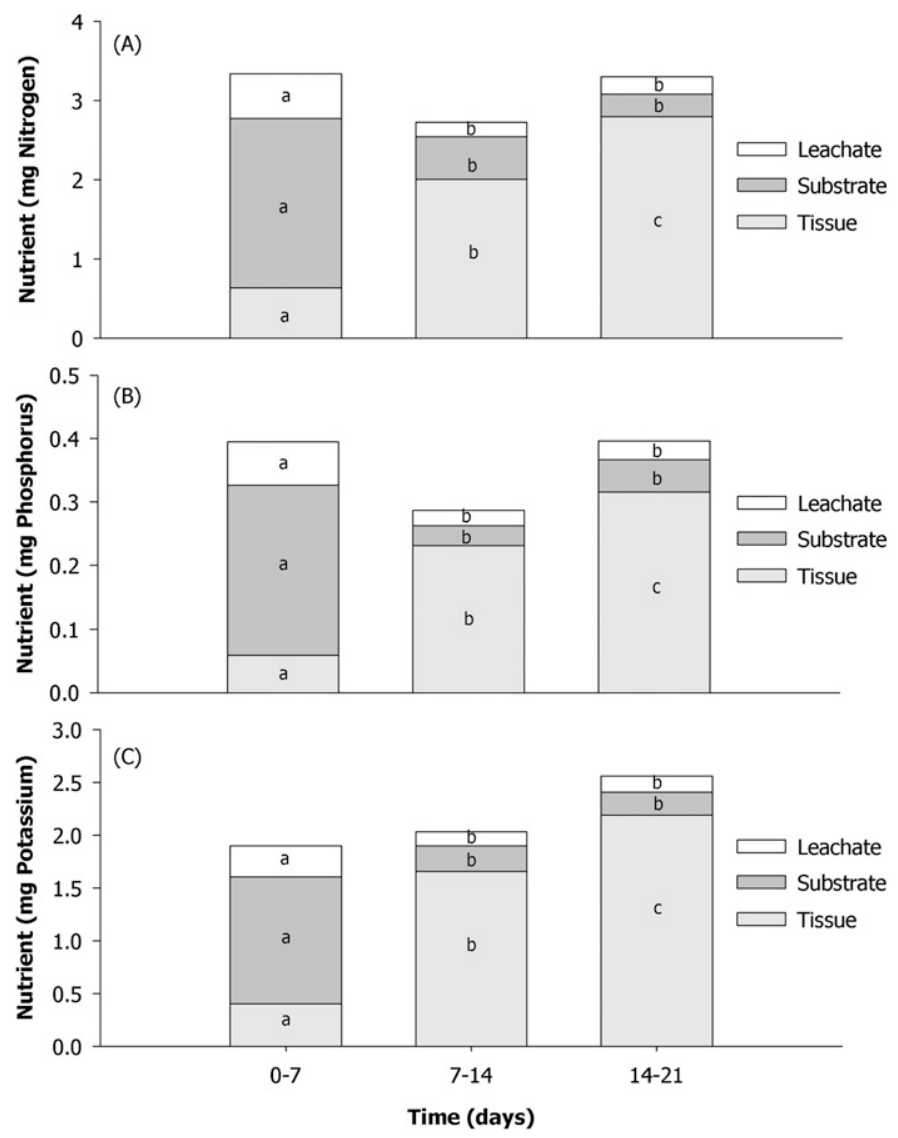

Fig. 3. Nitrogen (A), phosphorus (B), and potassium (C) in leachate, substrate, and tissue over time for plants receiving continuous complete ("C") fertilizer. Each bar represents the average of eight tray, divided by the number of cuttings per tray (102). Letters show mean comparisons across time within tissue, substrate, or leachate using Tukey's honestly significant difference at $P \leq 0.05$.

would be required to control the increased shoot growth or a lower constant macronutrient concentration could be applied. In the case of petunia 'Royal Velvet', the rate of fertilizer used in this experiment may have been too high and a reduction in fertilizer rate to a constant rate (for example, an average $76 \mathrm{mg} \cdot \mathrm{L}^{-1}$ $\mathrm{N}$ was used in the survey by Santos et al., 2008) might control excessive shoot growth. The results from this experiment were based on a particular plant species and cultivar, whereas response to fertilization during propagation could vary with other crop types.

During the first $7 \mathrm{~d}$ of propagation regardless of nutrient supply, tissue nutrient concentrations dropped. This response can be attributed to dilution because of growth that occurred in the first $7 \mathrm{~d}$ in conjunction with minimal uptake. A decline in tissue nutrient concentration was also observed in poinsettia (Euphorbia pulcherrima Willd. ex Klotsch) after $7 \mathrm{~d}$ under mist, and this decline was not correlated with three different rates of water volume applied (Wilkerson and Gates, 2005). A decline in tissue nutrient concentration also occurred in poinsettias that did not have any water applied to foliage $13 \mathrm{~d}$ after sticking (Svenson and Davies, 1995). The uniform decline in tissue nutrient concentrations during the first $7 \mathrm{~d}$ emphasizes the importance of high initial tissue nutrient concentrations in unrooted cuttings for subsequent plant health. If the tissue nutrient concentrations are low in the unrooted cutting, fertilizer applications need to be started as soon as possible or a reduction in growth and quality may occur as tissue nutrient concentrations drop below recommended ranges and nutrient deficiencies begin to limit growth.

Complete fertilizer applications during this initial drop in tissue nutrient concentration were shown to sustain higher tissue nutrient concentrations compared with cuttings receiving $\mathrm{M}$. The positive response to $\mathrm{C}$ fertilizer applications early in propagation could be attributed to uptake through foliar, cut stem, or root initials. High humidity environments such as propagation enable nutrients to stay in solution longer and are more available for foliar uptake (Clor et al., 1963; Dybing and Currier, 1961; Schonherr and Bukovac, 1972). Relative humidity and leaf water status have been shown to be key factors controlling foliar uptake (Bukovac and Wittwer, 1957; Tukey and Marczynski, 1984).

\section{Conclusions}

Overall, early nutrient supply had positive effects on growth and nutrient concentrations of petunia. However, mist fertigation involves a tradeoff in terms of increased potential for algae growth, increased nutrient runoff if the fertigation solution is not recycled (as evidenced by the low uptake efficiency; Fig. 3), and potential for phytotoxicity or minimal response in certain species. Early mist fertigation would therefore be favored in combination with an irrigation system that includes capture and reuse of leachate in addition to water sanitation for algae and pathogen control (for example, copper ionization or chlorination) for fast-growing species in which nutrient dilution may rapidly occur, in species that readily absorb nutrients through the foliage (lacking a thick cuticle and not prone to salt damage), and where initial tissue nutrient concentrations are low in the unrooted cuttings. Areas that warrant further investigation include the response to early application of macronutrients in plant species other than petunia and understanding which sites (leaf, cut stem, or callus) are important pathways for nutrient uptake or loss before root emergence.

\section{Literature Cited}

Biernbaum, J.A., W.R. Argo, B. Weesies, A. Weesies, and K. Haack. 1995. Persistence and replacement of preplant nutrient charge fertilizers from highly leached peat-based root media. HortScience 30:763.

Blazich, F.A. 1988. Mineral nutrition and adventitious rooting, p. 61-69. In: Davis, T.D., B.E. Hassig, and N. Sankhla (eds.). Adventitious root formation in cuttings. Dioscorides Press, Portland, OR.

Bukovac, M.J. and S.H. Wittwer. 1957. Absorption and mobility of foliar applied nutrients. Plant Physiol. 32:428-435.

Clor, M.A., A.S. Crafts, and S. Yamaguchi. 1963. Effects of high humidity on translocation of foliar-applied labeled compounds in plants part: I. Plant Physiol. 38:501-507.

Dole, J.M. and J.L. Gibson. 2006. Cutting propagation: A guide to propagating and producing floriculture crops. 1st Ed. Ball Publishing, Batavia, IL.

Dybing, C.D. and H.B. Currier. 1961. Foliar penetration by chemicals. Plant Physiol. 36: 169-174.

Gibson, J.L., D.S. Pitchay, A.L. Williams-Rhodes, B.E. Whipker, P.V. Nelson, and J.M. Dole. 2007. Nutrient deficiencies in bedding plants: A pictorial guide for identification and correction. Ball Publishing, Batavia, IL.

Good, G.L. and H.B. Tukey, Jr. 1967. Leaching of metabolites from cuttings propagated under intermittent mist. J. Amer. Soc. Hort. Sci. 89: 727-733.

Kerr, G.P. and J.J. Hanan. 1985. Leaching of container media. J. Amer. Soc. Hort. Sci. 110: 474-480.

Mills, H.A. and J.B. Jones, Jr. 1996. Plant analysis handbook. II: A practical sampling, preparation, analysis, and interpretation guide. MicroMacro Publishing, Athens, GA.

Mudge, K.W. 1995. Comparison of four moisture management systems for cutting propagation of bougainvillea, hibiscus, and kei apple. J. Amer. Soc. Hort. Sci. 120:366-373.

Rowe, D.B. and F.A. Blazich. 1999. Mineral nutrient and carbohydrate status of loblolly pine during mist propagation as influenced by 
stock plants nitrogen fertility. HortScience 32: 1279-1285.

Santos, K.M., P.R. Fisher, and W.R. Argo. 2008. A survey of water and fertilizer management during cutting propagation. HortTechnology 18:597-604.

Schonherr, J. and M.J. Bukovac. 1972. Penetration of stomata by liquids. Plant Physiol. 49:813-819.

Scoggins, H.L., D.A. Bailey, and P.V. Nelson. 2002. Efficacy of the press extraction method for bedding plant plug nutrient monitoring. HortScience 37:108-112.

Svenson, S.E. and F.T. Davies, Jr. 1995. Change in tissue mineral elemental concentration during root initiation and development of poinsettia cuttings. HortScience 30:617-619.

Tukey, H.B. and S. Marczynski. 1984. Foliar nutrition - Old ideas rediscovered. Acta Hort. 145:205-212.
Tukey, H.B., Jr., H.B. Tukey, and S.W. Wittwer. 1958. Loss of nutrients by foliar leaching as determined by radioisotopes. Proc. Amer. Soc. Hort. Sci. 71:496-506.

Wilkerson, E.G. and R.S. Gates. 2005. Transpiration capacity in poinsettia cuttings at different rooting stages and the development of cutting coefficient for scheduling mist. J. Amer. Soc. Hort. Sci. 130:295-301. 